\title{
RURAL TOURISM TO PROMOTE TERRITORIES ALONG THE ANCIENT ROADS OF COMMUNICATION: CASE STUDY OF THE REDISCOVERY OF THE ST. FRANCIS'S WAYS BETWEEN FLORENCE AND LA VERNA
}

\author{
Gianluca Bambi, Simona lacobelli, Giuseppe Rossi, Paolo Pellegrini, \\ Matteo Barbari ${ }^{1}$
}

Received 15 January 2019, Revised 31 January 2019, Accepted 5 April 2019

\begin{abstract}
This research project aims at identifying a new network of routes and historical itineraries for the development and promotion of rural tourism in the Tuscany Region, by promoting forms of sustainable mobility in rural areas, particularly marginal ones. Religious tourism is defined as tourism, which includes visits to religious sites such as shrines, churches, abbeys, hermitages and sacred places; such places are an attraction for their religious essence as well as their artistic and cultural beauty. The ancient obsolete road system, which often survives as an archaeological relic as a precursor of the present road system, especially in rural areas, is more widespread than a layman would think. The paper refers the results of the study aimed at recovering the entire historical road that allowed pilgrims and travelers to reach La Verna (a place where St. Francis received the Stigmata) coming from Florence.
\end{abstract}

Key words: rural tourism, ancient road system, St. Francis way, landscape

\section{Introduction}

Rural areas are facing significant social, economic, demographic, environmental challenges, such as depopulation, lack of financial resources and innovations, peripheral position, lack of employment opportunities and high quality services, etc. To foster development of rural areas, it is of key importance to identify specific resources of these territories. Creating a connection among nature, traditions, monuments, authentic products (arts and crafts, food, wine, etc.), social networks, can represent an important factor for development of these peripheral areas. Sacred cultural heritage, with a high artistic and historical value, plays an important role in this process, because churches, usually centers of rural communities and their cultural life, monasteries and other shrines could be the main drivers of sustainable socio-economic and cultural development of many rural areas (Makuc, 2015). Religious tourism is defined as tourism of religious sites such

\footnotetext{
1 Università degli Studi di Firenze, Department of Science and Technology in Agriculture, Food, Environment and Forestry (DAGRI), Firenze, Italy; Gianluca Bambi: gianluca.bambi@unifi.it, ORCID: 0000-0002-5838-0152; Simona lacobelli, simona.iacobelli@unifi.it; ORCID: 0000-0002-3995-4325; Matteo Barbari, matteo.barbari@unifi.it, ORCID: 0000-0002-0760-8604; Giuseppe Rosi, giuseppe.rosi@unifi.it, ORCID: 0000-0003-0211-9294
} 
as shrines, convents, churches, abbeys, hermitages and sacred places: such places are an attraction for their religious essence, but also for their artistic and cultural beauty.

This type of tourism is constantly growing since the first international religious tourism exchange was founded, organized in San Giovanni Rotondo (Foggia, Italy). Religious tourism is one of the fastest growing niche markets. The World Tourism Organization (WTO) expects the tourism sector to increase between 3 and 4\%, in which the growth of religious tourism is an important part. The WTO estimates between 300 and 330 million people are visiting the major sites of pilgrimage in the world (Canalis, 2010). Tours of Romanesque churches, Gothic cathedrals or Greek monasteries are examples of experiences that lie between tourism and religion (Timothy and Olsen, 2006). A complex reality, in which the visit to the sacred spaces may include other motivations, such as cultural or recreational purposes, so it can be said that today, some travel, undertaken for religious reasons, may involve non-religious activities. In the first case, some scholars share Blackwell's theory (Blackwell, 2007), which holds that sacred sites welcome visitors with very different motivations for their travel: from pilgrims (for whom the place is deeply meaningful) to visitors that flock out of tourist curiosity. In the latter, Santos (2003) uses the term religious tourism to speak of certain religious movements inspired by but not restricted to acknowledged sacred spaces, responding to spiritual needs for renewal or temporary retreat.

Thus, dividing lines are thin. In fact, religious tourism is a term that has been used to describe all situations that include tourism and religion, or travel and religion. It can therefore be defined as all types of tourism (voluntary, temporary and unpaid) motivated by religion (combined with other motives or by itself) and to a religious destination (local, regional, national or international), but for which the journey itself is not a religious practice (Aulet and Hakobyan, 2011). Authors as Smith (1992) and Santos (2003) believe that religious tourism should be seen not as mere tourism or business, even though it uses the infrastructure that is part of the tourism industry.

Given its spiritual dimension, religious tourism escapes common nomenclatures such as leisure or green tourism. Similarly, religious tourism must be clearly differentiated from pilgrimage, since the former has neutral connotations and is not in itself an act of worship, while the pilgrimage involves prayer and supplication (Aulet et al., 2015). Religious itineraries often run along an historical road, which in many cases survives only in the form of an archaeological find, especially in rural areas.

Today, the subject of the Pilgrim's routes fascinates not only archaeological researchers, but the public at large. This new development has prompted the public and private sector to renew its interest in the promotion of historical monuments, including ancient road systems, stimulated by its economic potential, in particular, religious and cultural tourism.

These new forms of fruition come today under the heading of rural tourism, which can bring benefits to all interested parties (tourists, tourism businesses, local population), by promoting a correct use of the environmental, historical, artistic, cultural heritage. This may become one of today's most profitable sectors of local economy, and especially in so-called marginal areas, creating both revenue and jobs.

Depopulation of rural areas poses great economic, social, demographic, cultural and environmental challenges; therefore, well-developed and well-managed cultural heritage assets could create employment opportunities, preventing depopulation and stimulating regional and local economy and creativity (Makuc, 2015).

Sustainable development is a major conceptual framework for community and social development, and it typically incorporates a long-term perspective on resource exploitation (Amir et al., 2015). A general definition of sustainable development that is widely used for tourism-based communities is the so-called "triplebottom-line", in which policies and actions attempt to balance social, economic and environmental costs and benefits (Hall and Lew, 2009). This is because tourism is often viewed as an economic activity first, although it can also conflict with the environmental and cultural conservation goals of community sustainability. Sustainable development is also one of the most common prescriptions for making a community more resilient (Edwards, 2009). 
The assumption is that a sustainable community is more resilient than a community that has not adopted significant sustainable development policies (Folke et al., 2002). One of the fastemerging sectors of small business is small tourism business in rural settlements (so-called "rural tourism") which is well represented in such countries as Hungary, the Czech Republic, Poland, Slovakia, Great Britain, France, Italy and others.

It is noteworthy of the fact that according to some sources, in the EU countries, $10-20 \%$ of the income from tourism involves rural tourism (Paresishvili et al., 2017). The outcomes identified in this research are found mostly in rural areas, where there are many farms that are also "agritourism" or farm tourism with direct sale of their rural products.

\section{Cultural routes, landscape and rural tourism}

In the programs of the International Council on Monuments and Sites (ICOMOS) and the United Nations Educational, Scientific and Cultural Organization (UNESCO) as well as in the Council of Europe Resolutions on Cultural Itineraries, the request of the landscape enhancement is clearly expressed.

The ICOMOS Charter on Cultural Routes states that "the Cultural Route is closely linked to its setting and forms an inseparable part of it [...] The territorial setting, whether natural or cultural (urban or rural), provides the framework of the Cultural Route, gives it its particular atmosphere, characterized by elements and values of both physical and intangible nature, and is fundamental for the comprehension, conservation and enjoyment of the route (CIIC, 2008).

The same document also expressly refers to the landscape realizing that "Cultural Routes and their setting are related to their different landscapes, natural or cultural [...] The different landscapes contribute to characterize the diverse sections of the Route as a whole, enriching it with their diversity" (CIIC, 2008).

In the UNESCO Report on Routes as a Part of our Cultural Heritage, the relationship between routes and landscape is expressed as an identity. In fact, "a heritage route may be considered as a specific, dynamic type of cultural landscape" (UNESCO, 2011).

Council of Europe Resolutions on Cultural Routes (CM/Res (2007) 12, CM/Res (2010) 52) identify them as sites of experimentation for European Chartes, first of all the European Landscape Convention (Berti and Mariotti, 2015).

Europe has in its walkable landscape, in this footprint geography, a pillar of its cultural identity (Steiner et al., 2006) and Italy, where the Way of Saint James and the Way of Jerusalem are superimposed on the itinerary of the Via Francigena, holds a prime position. Italy has a network of 44 Cammini, recognized by the Ministry of Cultural Heritage and Activities and Tourism (MiBACT, 2016) for their historical-cultural interest.

Whilst following, in most cases, ancient pilgrimage routes, these itineraries are not strictly related to religious tourism which involves shrines, convents, churches, abbeys, hermitages and sacred places. They are doubtless an attraction for their religious essence, but they are often of great artistic and historic value. In many cases, the road gave the basic imprint (Turri, 1998) to a territory, and cities and villages were generated from it. The route is the driving force in creating the sequence of the intersections, shaping economies, territories and landscapes on a transregional scale, the so-called road-territory as in the case of the Via Francigena.

The tourism generated along the cultural itineraries can be considered rural tourism, in its widest acceptation. Rural tourism, in fostering the discovery of wine and food, agriculture and typical handicrafts, becomes a great potential for a wide range of economic development and represents that form of tourism that today takes the name of "experiential tourism". The tourist/pilgrim wants to live an emotional experience whose personal achievement is based on the enjoyment of one or more of the following components: culture, landscape, food and wine, encounter, welcome and relationship with local communities. According to a study of the Tuscan Region done in 20152016 along the Via Francigena in Tuscany, from a questionnaire filled by 1000 pilgrims/walkers, it appears that the enjoyment, the experiential knowledge and the understanding of the crossed landscape are their higher expectations (Bambi and lacobelli, 2017). 


\section{Methodology}

Concerning the itineraries for places linked to the memory of St. Francis of Assisi, it is necessary to specify among those obtained from the "Franciscan sources" (biographies written within the first century after the death of St. Francis in 1226) and those which come from local traditions, often handed down orally. In this second case, even in the absence of references in the "Sources", it is still possible to speak of Franciscan places, sites linked to the memory of the Saint of Assisi that convey the human and Christian message. Florence and La Verna are the only sure places of the presence or passage of Saint Francis in the territory, while others are questioned by historians. For this reason, the probable roads used by the Saint are largely unknown.

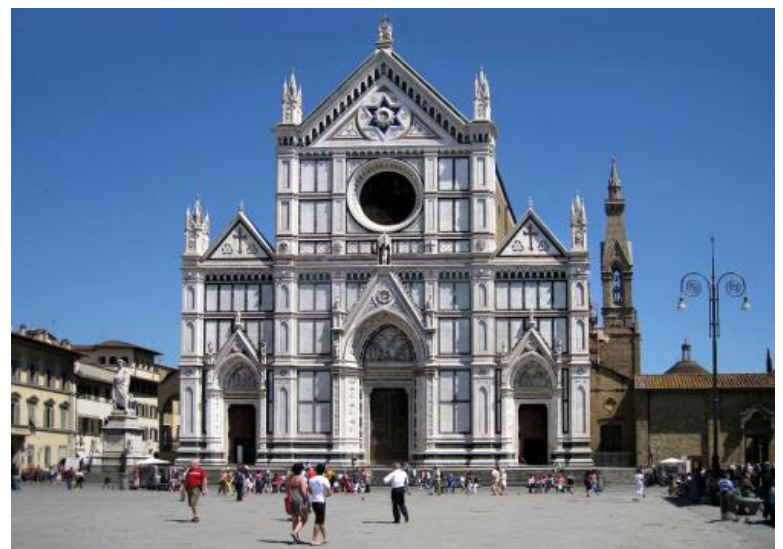

Fig 1. Basilica of Santa Croce in Firenze. Source: Gianluca Bambi

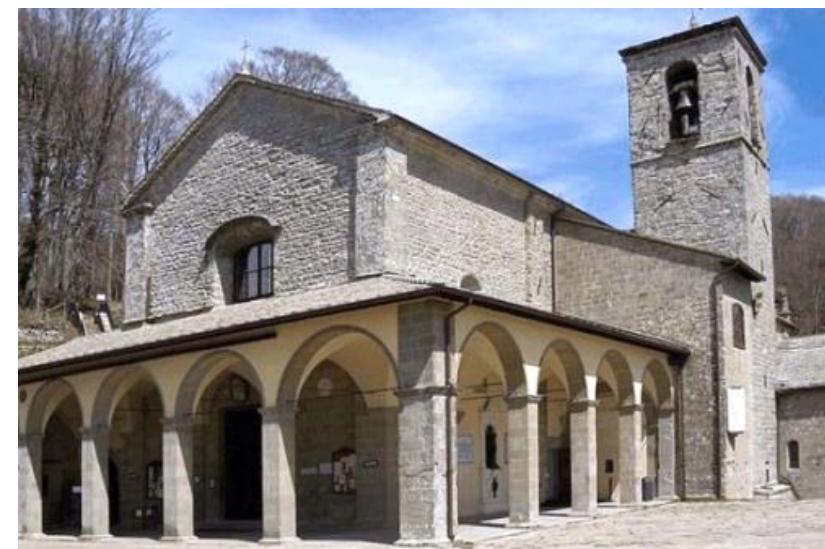

Fig 2. Sanctuary of La Verna. Source: Gianluca Bambi

A first presence of Franciscan Minor Friars in Florence can be dated to 1208, when the friars Bernardo and Egidio arrived there, and the Florentine tradition has linked the origin of the hospital of San Gallo to this presence. In 1217 Francis, en route to France, passed through Florence, and there he met Cardinal Ugo (also known as Ugolino) of Ostia, who advised him to go back to deal with the approval of his fraternity by the pope. Between the years 1220 and the 1250s, the first convent of the Friars Minor was built and then enlarged, which later became the current Basilica of Santa Croce (Figure 1). The Sanctuary of La Verna (Figure 2) is linked to the episode of the stigmatization of St. Francis, which took place in the year 1224 (in the month of September, perhaps on the 17th). All the ancient biographies of Francis of Assisi speak of this episode. Other places that have been linked to St. Francis from the tradition developed between the late Middle Ages and the modern age are still considered in the path of St. Francis. For centuries, his legacy marked the steps of a pilgrimage and contributed to shaping the identity of the territory, whose people considered - and continue to consider - St. Francis of Assisi to be an important point of reference.

The historical routes, connecting Florence with the Sanctuary of La Verna, have seen the passage of pilgrims and wayfarers for centuries and are obviously better known and identifiable in historic maps. Consequently, identification of the paths was based on the presence of historical routes and passages connected St. Francis's time and subsequent ones. The identified paths are included among those that for centuries have represented the main arteries connecting Florence and the Casentino Valley (where the La Verna Sanctuary is placed).

For the study, the historical cartography has been taken directly from the Tuscany Region Database imported into a GIS for comparison with the current state of these tracks. The cartography of the Inghirami (1830) (Figure 3) and the Leopoldina map (Figure 4) by CASTORE project has been used.

CASTORE_WMS is a WMS OGC service of Tuscany Region, specifically dedicated to publishing maps of the CASTORE Project (Regional Historical Charts). The CASTORE project was carried out in collaboration with the Tuscan State Archives, based on an agreement stipulated with the Ministry for Cultural Heritage and Activities. The project involved high-resolution digital reproduction of over 12,000 historic maps from the 1800 s, their cataloging and geo-referencing. 


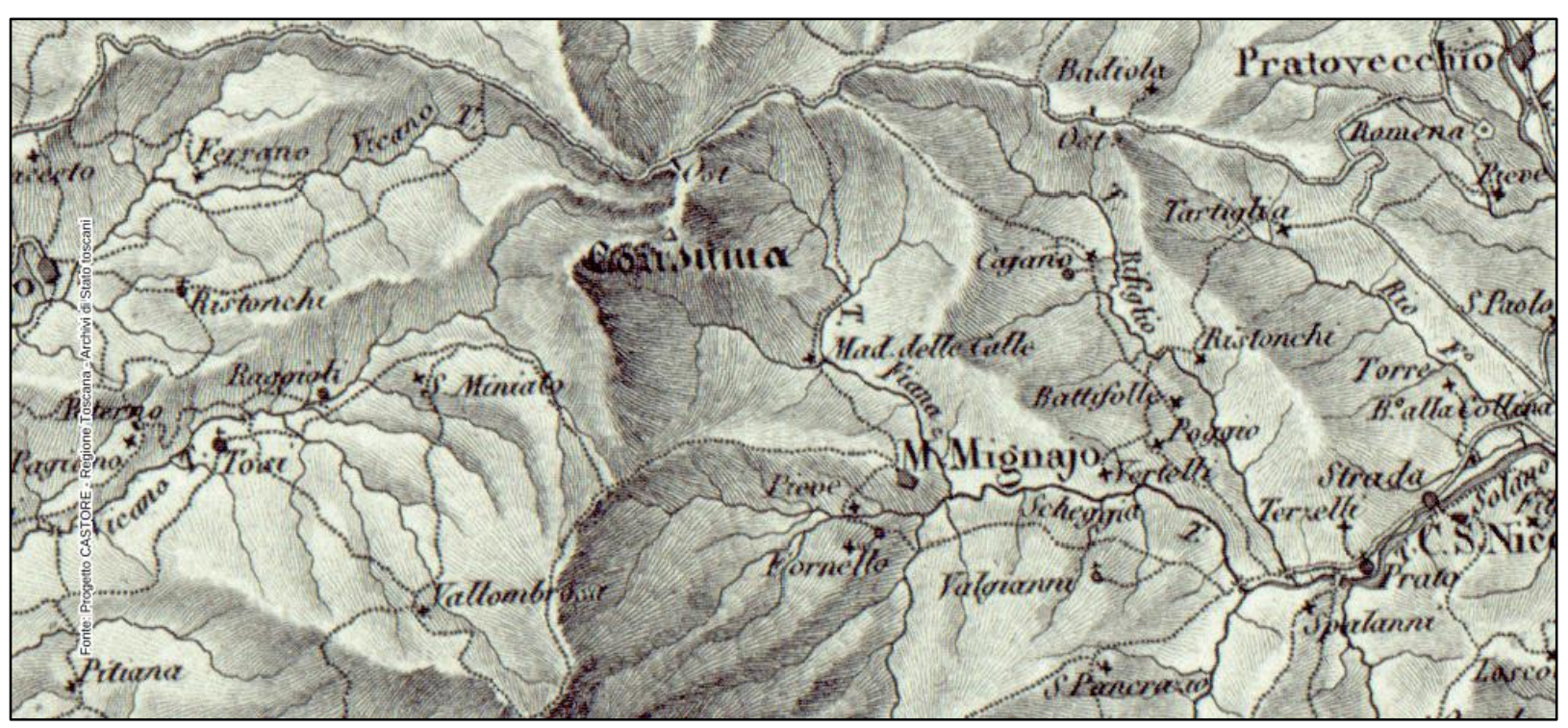

Fig 3. Historical map Inghirami of 1830 where the ancient tracks and passes are located.

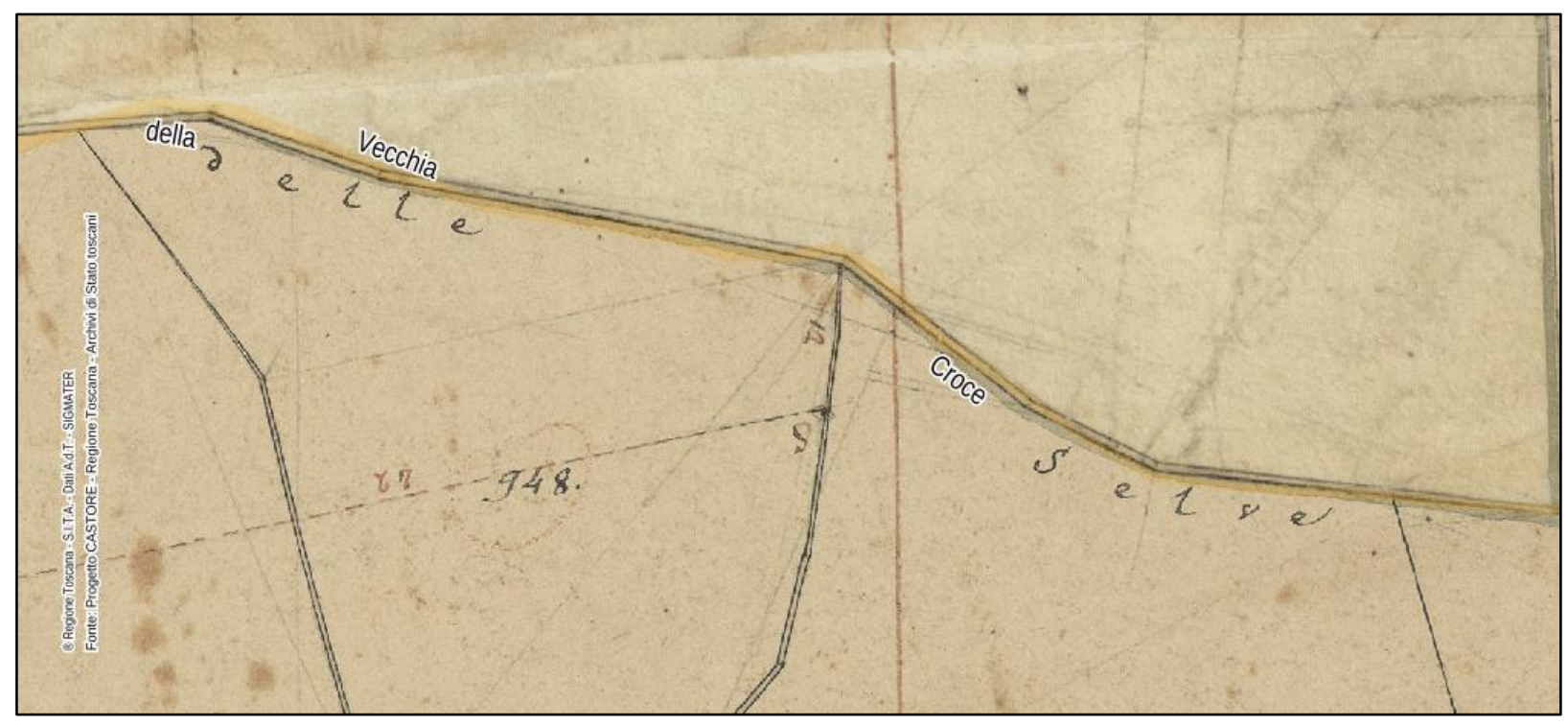

Fig 4. Detail of "Leopoldine" historic maps of the end XIX century reporting the historical road system.

The study is focused on interest in natural, archaeological, historical and artistic resources present along these ancient roads, with a special focus on possible tourist buildings, rural farms, small villages, parks, protected areas, etc.

GIS can be helpful to tourism as a valuable tool for managing, analyzing, and displaying large volumes of diverse data to many different levels of planning activities. A GIS is able to create suitable links between spatial and tabular data, and discover spatial relationships between the features of maps. It helps to collect, store and integrate spatial data to analyze and present them as new information. The results of the GIS analysis are important when comparing different ancient maps in locating the historic path and possible touristic or cultural itineraries, which can form the basis for proper planning and territorial management.

Figure 4 shows an overlap between the old Via Florentina, drawn on an historical map, and the current path that has been located directly on the field with the GPS. In this manner, it is possible to reconstruct the relationship between the old path and the territory transformation that affected the land along the old route, through a comparison of historical documents and the current situation. 
In addition to the historical cartography, the IGMI digital cartography (Istituto Geografico Militare Italiano), the technical mapping 1:10000 and 1: 2000 of the Tuscany Region and the aerial photos of the area have been used. The data related to the identified paths were grouped by themes and included in the GIS as a shapefile (.shp), creating digital thematic maps, easy to view and update.

In a second part of the research, a survey of the routes will be carried out, directly using GPS instruments to create a complete database of routes and areas of interest.

A GIS analysis has also been carried out to characterize the territories that surround and intersect the path, in order to evaluate the socio-economic impact of their passage through territories, especially marginal ones.

For the analysis, the database "ISTAT and Regione Toscana - ISTAT 2001 and 2011 Census" was used, in shapefile format, provided in Gauss-Boaga Fuso Ovest coordinates (EPSG code: 3003). This database contains information about:

- identification data (census, ISTAT code of the municipality, cadastral code, name of the municipality, number of the census section, inhabited locality of belonging;

- geometric column (containing geometry description of the section or locality);

- fields containing the ISTAT census variables and the relative densities calculated by comparing the values to the section (or locality) area.

Regarding the density values reported in the census, four values were chosen to carry out the analysis, in relation to their potential ability to describe the "marginality" of an area. In particular:

- DP1_Density per $\mathrm{km}^{2}$ of resident population;

- DP62_Density per $\mathrm{km}^{2}$ of workforce, unemployed persons and other jobseekers;

- DE1_ Density per $\mathrm{km}^{2}$ of buildings and building complexes;

- DI1_Density per $\mathrm{km}^{2}$ of local business units.

The census also identifies types of locations, defining 3 classes:

1. Residential center. Aggregate of neighboring or neighboring houses with interposed streets or squares characterized by the existence of services or public exercises (school, public office, pharmacy, shop or similar), which constitute an autonomous form of social life and, generally, also a gathering place for the inhabitants of the surrounding areas in order to demonstrate the existence of a community life coordinated by the center itself.

2. Small residential center. Inhabited area, devoid of the gathering place that characterizes the Residential center, constituted by a group of at least fifteen adjacent and neighboring buildings, with at least fifteen families, with interposed roads, paths, squares, farmyards, small gardens, uncultivated areas, even though the interval between house and house does not exceed thirty meters.

3. Sparse houses. Houses spread in the municipal area at a distance that could not even constitute a population.

For the analysis, all the locations that intersect the St. Francis way (Figure 5) have been selected, except for those classified as "Sparse houses" as they are considered unsuitable to offer possible services for walkers. 


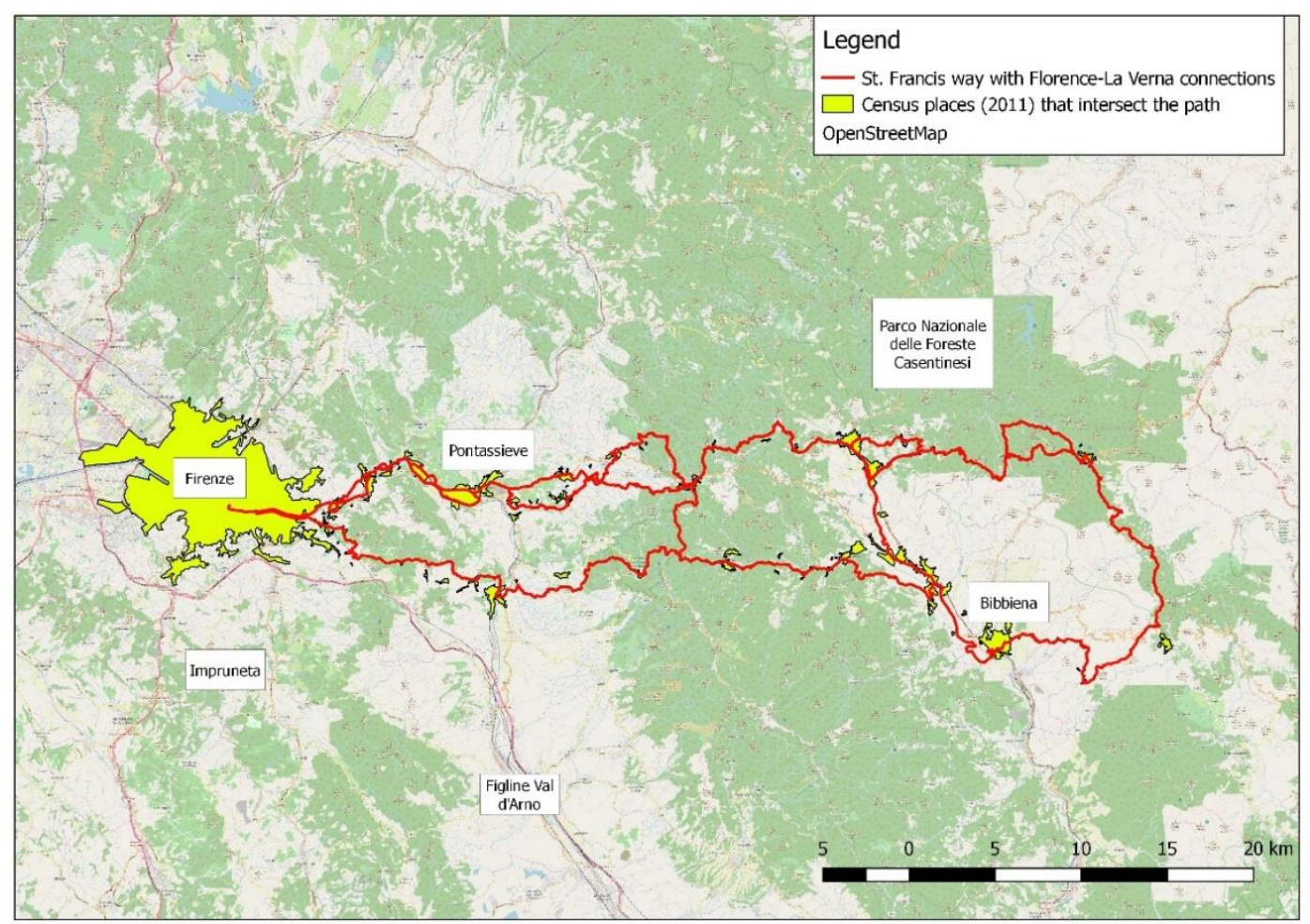

Fig 5. Cartographic extract with detail of the St. Francis way and localities crossed by it.

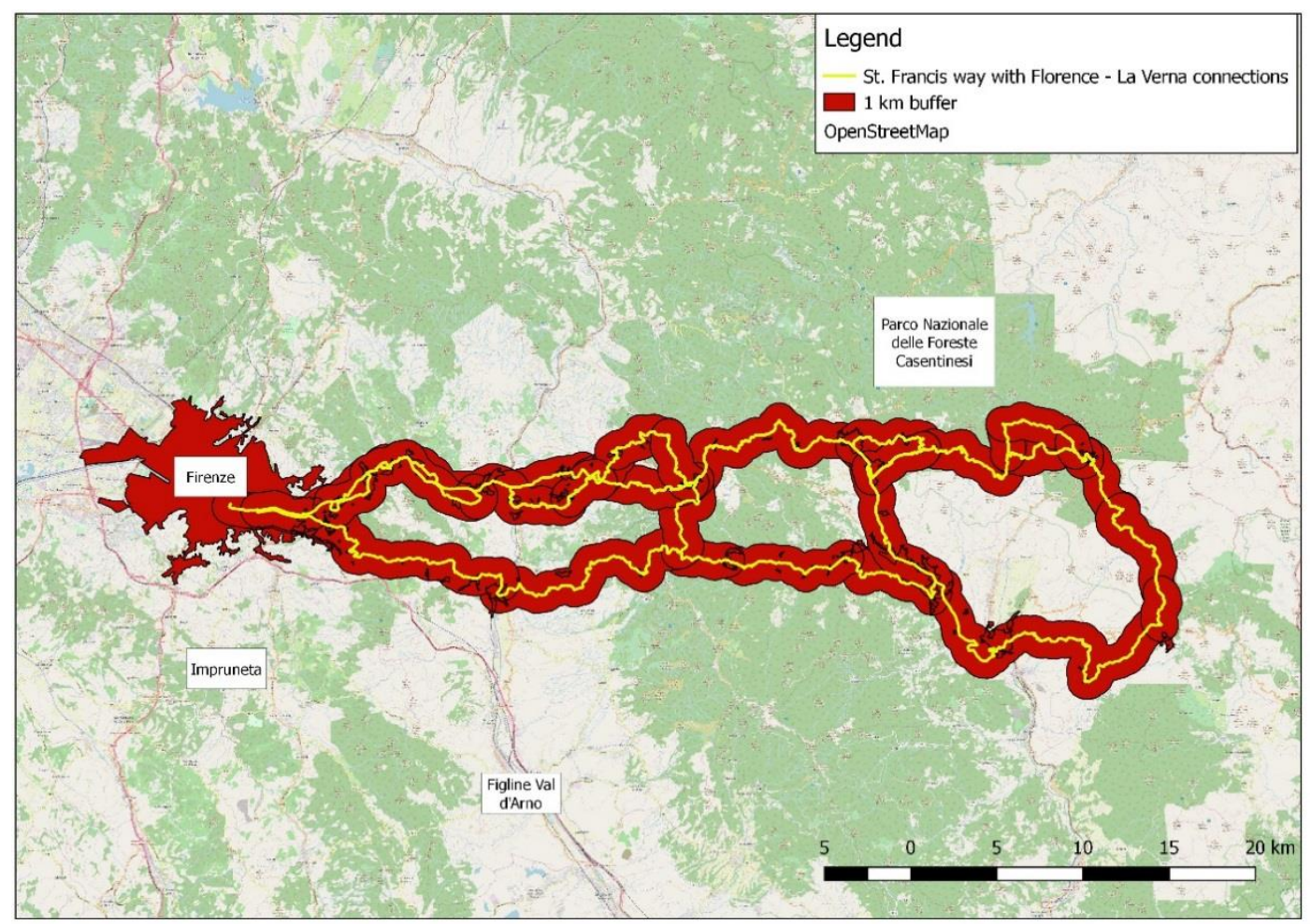

Fig 6. Buffer detail of $1 \mathrm{~km}$ to the right and to the left of the path.

Hereafter, a $1 \mathrm{~km}$ buffer was created on the right and left of the path (Figure 6). The choice of the buffer of $1 \mathrm{~km}$ is aimed at investigating the probable area of use around the path: $1 \mathrm{~km}$ is, in fact, the distance that is considered most appropriate to describe the territory surrounding the path, in terms of marginality and, therefore, of possible development of these territories through the promotion of the journey. 


\section{Results}

In order to promote communication and to contribute to an enhancement of the St. Francis way, the results of the present work consist in creating an innovative network through GPS survey, entering geographical data, and information within an especially designed GIS database. In this way, it is possible to survey the route network in its entirety, quantifying and monitoring the main characteristics of this road. Each itinerary will bring an alpha-numeric recognition and information related to travel time, length, difficulty, emergencies, etc. This will create a network of routes that for the most part pass through rural areas, and can certainly represent an opportunity for tourism development in those territories that today suffer from isolation (Bambi and Barbari, 2014).

After a careful analysis of both the historical and the modern maps, two directives were identified from Florence (Basilica of Santa Croce) to reach the Sanctuary of La Verna:

1) the passage crossing Consuma pass;

2) the passage crossing Croce Vecchia pass.

Both these routes are approximately $100 \mathrm{~km}$ long, which can be travelled in 5-6 stages depending on the needs and physical characteristics.

The GIS analysis of $1 \mathrm{~km}$ buffer has allowed to extract information concerning the characteristics of the territory surrounding the St. Francis way. The figure 7 shows that the type of locality most represented is the "small residential center" with $53 \%$, while the "residential centers" represent the $47 \%$. Regarding the resident population density (Figure 8 ), the $14 \%$ of the localities show values of resident population density between 2000 and 2500 inhabitants per $\mathrm{km}^{2}$, while the $12 \%$ show values for the range 1500-2000 inhabitants per $\mathrm{km}^{2}$ and $12 \%$ for the range between 250 and 500 inhabitants per $\mathrm{km}^{2}$. In general, it is observed that localities around the St. Francis way are characterized by a number of inhabitants less than 2000 per km$^{2}$ (around 54\%; Figure 9).

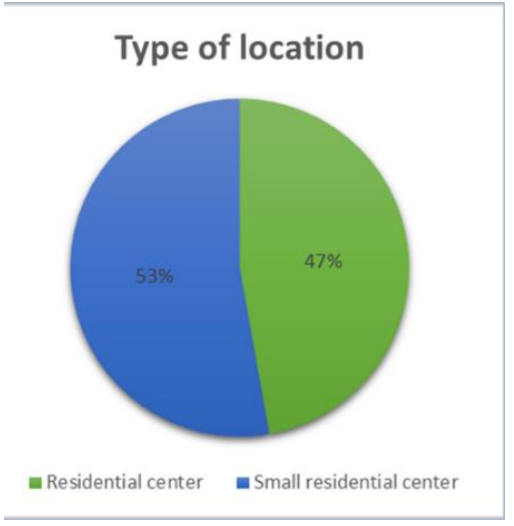

Fig 7. Distribution of locations

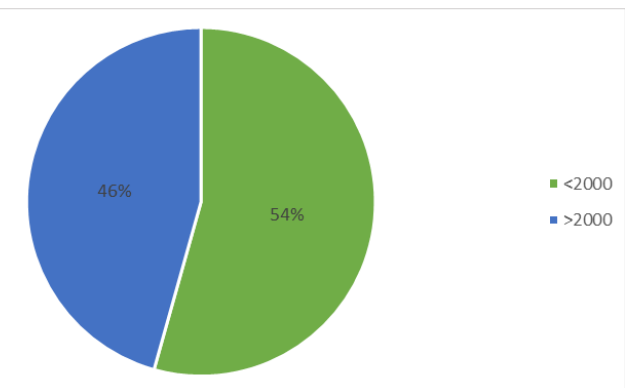

Fig 9. Resident population density divides into two classes.

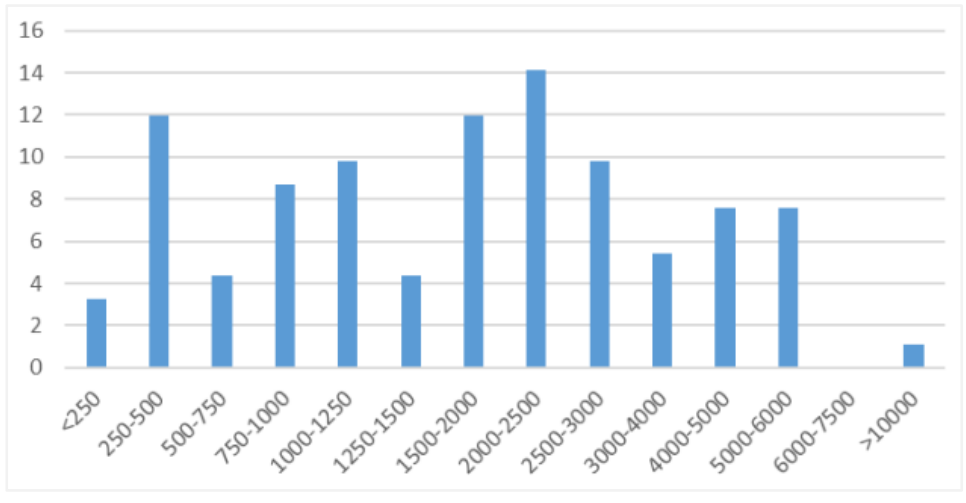

Fig 8. Classes of density for resident population.

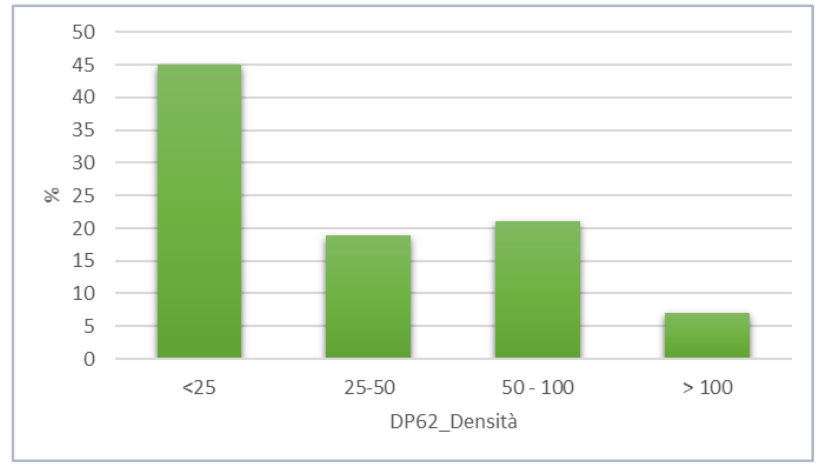

Fig 10. Classes of density for workforce. 
Analyzing the indexes relative to the workforce, figure 10 shows the highest percentage $(49 \%)$ of unemployment per $\mathrm{km}^{2}$ lower than 25 . In figure 11, unemployment is represented per $\mathrm{km}^{2}$ grouped by municipalities, with $18.4 \%$ referring to the municipality of Castel San Niccolò.

Figure 12 shows the density values per $\mathrm{km}^{2}$ of buildings and building complexes: $31 \%$ of localities with density values between 500 and 750 buildings and building complexes per $\mathrm{km}^{2}$, the $25 \%$ of density values between 500 and 750 and the $21 \%$ of localities with density the range values 1000-2000. Finally, the $37 \%$ of localities have less than 30 local businesses per $\mathrm{km}^{2}$ (Figure 13).

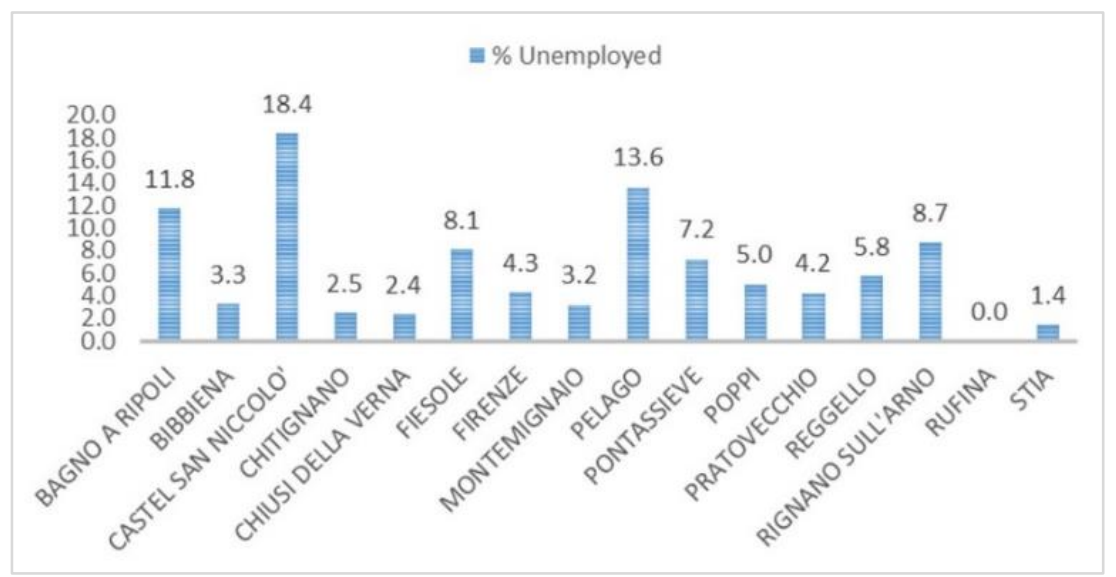

Fig 11. Percentage unemployed grouped by municipality.

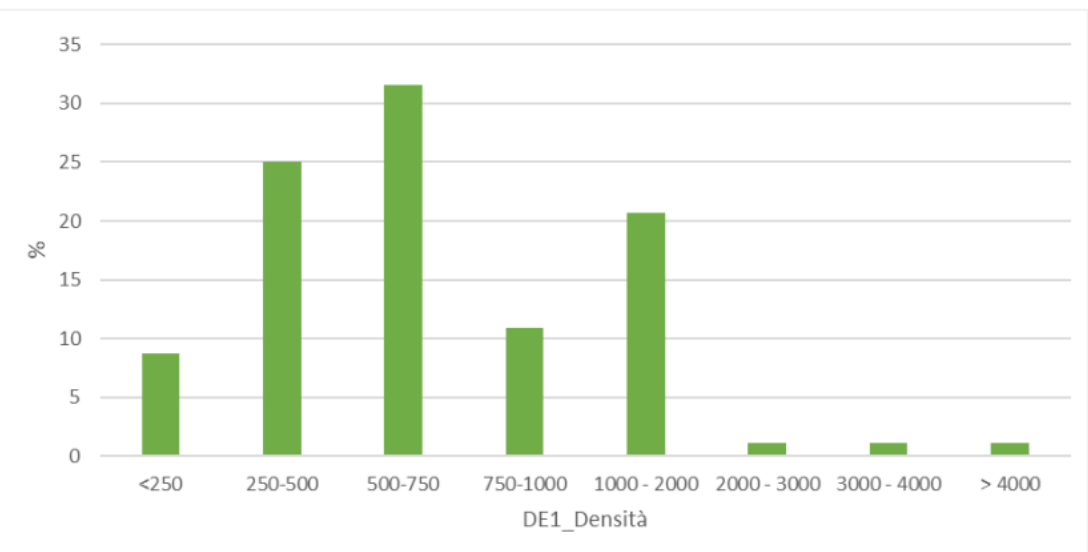

Fig 12. Classes of density for buildings and building complexes.

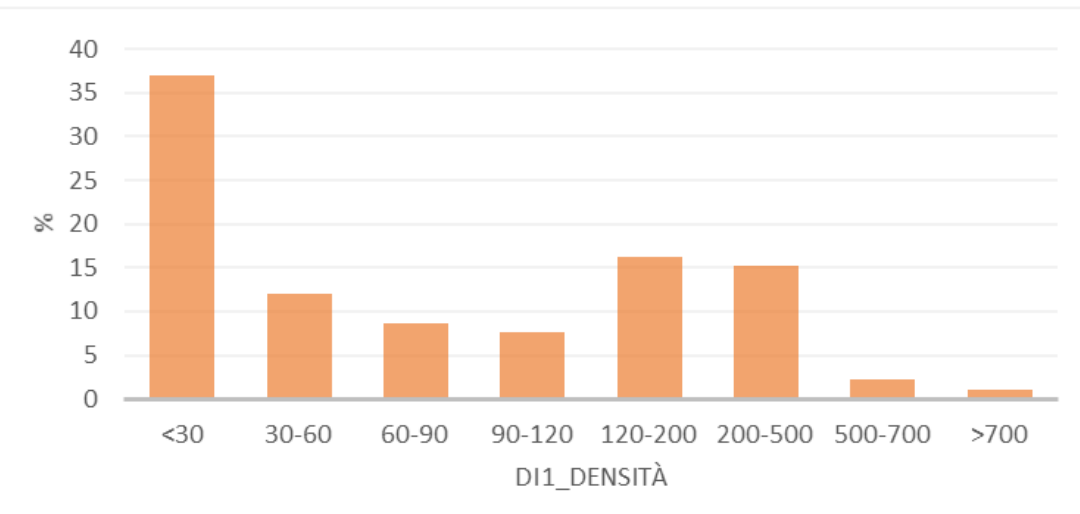

Fig 13. Classes of density for local business units. 
The following steps were followed for defining an itinerary along the routes of St. Francis way, with the aim to promote the cultural, natural and historical heritage for tourist purposes identification of the historic places and paths the route should run through:

- selection of the most important points of interest to be included (like services for the tourist/pilgrims);

- creation of a geo-database, with different attribute tables;

- design and creation of the itinerary using GIS and GPS survey

- insertion of the points of interest in the GIS

Subsequent actions include ensuring the safety and marking of all paths (Figure 14). The different socio-economic analysis set up on the GIS provides a great deal of this information which will then be verified through the monitoring of the real flow along the St. Francis way throughout the years.

Additional results that we expect from this project in the future include:

- development of communication and promotion of the territory in order to create a unique product (called "The Routes of St. Francis " of Tuscany) making the area between Florence and La Verna a single territorial entity;

- promotion of typical local products through quality rural tourism;

- protection and promotion of natural and forest resources, biodiversity and the preservation of the landscape;

- increased participation of the agricultural and agri-food sector in the local economic development process, particularly in the rural tourism sector;

- promotion of local businesses found along the routes that offer services for different tourist targets that the project wants to reach (tourists, walkers, pilgrims and others).

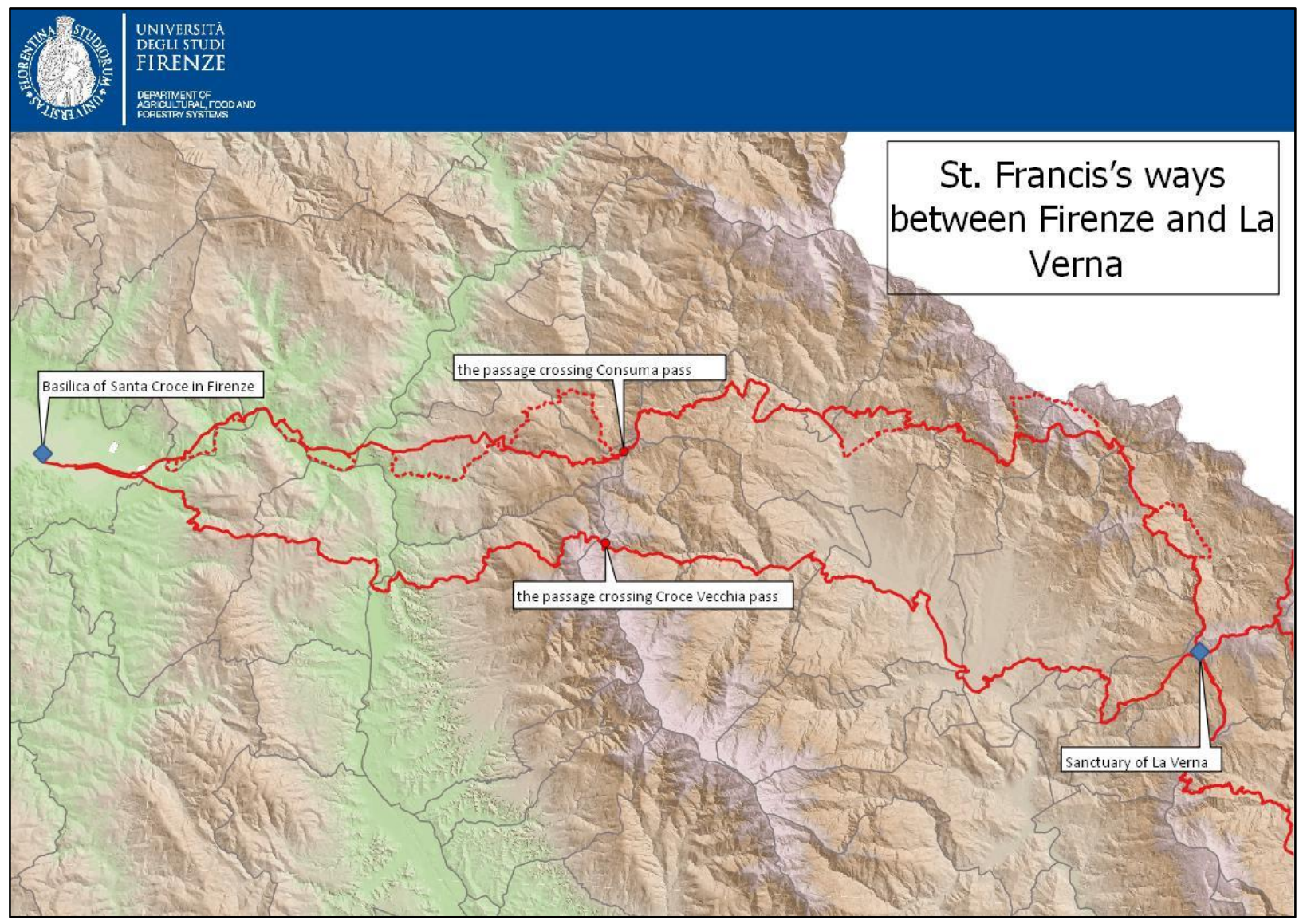

Fig 14. Cartographic extract of the route identified for the St. Francis way, with the two historical ways individuated. 


\section{Conclusion}

The main objective of the research project was to identify a series of itineraries that could unite sites linked to the life of St. Francis and also to restore historical routes that have allowed pilgrims and travelers to travel from Florence to La Verna for centuries. This will create a network of routes that for the most part pass through rural areas, and can certainly represent an opportunity for tourism development in those territories that today suffer from isolation. The research aims to enhance these territories through rural tourism by creating and promoting activities, events and projects about sustainable mobility and whose objectives are to strengthen the network of itineraries that make up the project "The Routes of Francis" in Tuscany and throughout Italy. These routes are aimed at all potential users, such as tourists, walkers, school groups, pilgrims, families and disabled people interested in walking, biking and riding.

All cultural itineraries, but especially linear itineraries that follow ancient pilgrim routes, by their nature, can narrate their landscapes. The landscape unfolds itself along its typical routes, which have a typical way of driving within the landscape, telling its story.

These itineraries can be an excellent tool for maintaining the territory and the landscape in a sustainable way, contributing to the socio-economic survival of rural areas, enhancing the typical agro-food, contributing to the dissemination of cultural identity and intergenerational exchange, recover the historical heritage of the old streets and annexed structures, fostering the sustainable development of tourism, the stimulation of healthy habits of life such as walking, the carrying out of historical-cultural educational activities.

For farmers, craftspeople and other productive structures itinerary can be a valuable economic opportunity through which territories can preserve their identity and develop themselves in a sustainable way. Itineraries can be the best means for preserving and enhancing the territory and especially its traditional cultural landscape in sustainable ways, contributing to the socioeconomic subsistence of rural areas, enhancing agro-food typical product, contributing to the dissemination of cultural identity and intergenerational exchange, restoring the historical heritage of the ancient streets and the annexed structures, favouring the sustainable development of tourism, and finally encouraging healthy lifestyles through historical-cultural and educational activities.

These new forms of fruition come today under the heading of rural tourism, which can bring benefits to all interested parties (tourists, tourism businesses, local population), by promoting a correct use of the environmental, historical, artistic, cultural heritage. This may become one of today's most profitable sectors of local economy, and especially in so-called marginal areas, creating both revenue and jobs.

The rural tourism, integrating itself with the offer of eno-gastronomic, agricultural and handcrafted products, becomes economic development and can represent that form of tourism that today takes the name of "experiential tourism". The tourist / pilgrim wants to live an emotional experience that is based on one or more of the following ingredients: culture, landscape, food and wine, encounters and relationships with the local community.

Presently, it promotes the use of forgotten or under-explored resources enabling economic sustainability and providing funds for cultural activities. It includes not only urban areas, but also rural areas showcasing the traditions of indigenous cultural communities, their values and lifestyle.

The GIS analysis allowed us to highlight the characteristics of the territory surrounding the route of St. Francis. "Small residential centers" represent the majority of the sites. Furthermore, all the indices chosen to characterize the territory, especially those related to unemployment and the density of local business units, show their relative isolation. The St. Francis way can represent an effective tool for the socio-economic development of these areas.

\section{Acknowledgement}

The Authors want to express their gratitude to the Tuscany Region for its support of this study. 
[1] Amir, A. F., Ghapar, A. A., Jamal, S. A. \& Ahmad, K. N. (2015). Sustainable Tourism Development: A Study on Community Resilience for Rural Tourism in Malaysia, Procedia Social and Behavioral Sciences, 168, 116-122. DOI: 10.1016/j.sbspro.2014.10.217.

[2] Aulet, S. \& Hakobyan, K. (2011). Turismo Religioso y espacios sagrados: Una propuesta para los santuarios de Catalunya. Revista Iberoamericana de Turismo, 1(1), 63-82.

[3] Aulet, S., Vidal, D. \& Crous, N. (2015). Religious and spiritual tourism as an opportunity for rural tourism: the case of Girona. In Bambi, G. \& Barbari, M., eds., The European Pilgrimage Routes for promoting sustainable and quality tourism in rural areas (pp. 703-713). Firenze University Press.

[4] Bambi, G. \& Barbari, M. (2015). La Via Francigena toscana: idee e soluzioni progettuali per la promozione e lo sviluppo del turismo rurale ed escursionistico. In: Barbari, M. \& Sorbetti Guerri, F., eds., Edilizia rurale tra sviluppo tecnologico e tutela del territorio (pp. 455-462). Firenze University Press.

[5] Bambi, G. \& lacobelli, S. (2017). Study and Monitoring of Itinerant Tourism along the Francigena Route, by camera trapping system. Almatourism 8(6), 144-164, DOI: 10.6092/issn.2036-5195/6663.

[6] Berti, E. \& Mariotti, A. (2015). The heritage of Cultural Routes: between landscapes, traditions and identity. In Cultural Routes management: from theory to practice. Strasbourg: Council of Europe.

[7] Blackwell, R. (2007). Motivations for religious tourism, pilgrimage, festivals and events. In Raj, R. \& Morpeth, N. D., eds., Religious tourism and pilgrimage festivals management: An international perspective (pp. 35-47). Wallingford: CABI Pub.

[8] Folke, C., Carpenter, S., Elmqvist, T., Gunderson, L., Holling, C. S. \& Walker, B. (2002). Resilience and Sustainable Development: Building Adaptive Capacity in a World of Transformations. AMBIO 31(5), 437-440. DOI: 10.1579/0044-7447-31.5.437.

[9] Edwards, C. (2009) Resilient Nation. London: Demos.

[10] Hall, C. M. \& Lew, A. A. (2009). Understanding and Managing Tourism Impacts: An Integrated Approach. London: Routledge.

[11] Makuc, N. (2015). Fostering socio-economic development of rural areas through cultural and religious tourism: innovative solutions for involvement of private sector. Firenze University Press.

[12] Marino, D., Nofroni, L. \& Savelli, S. (2015). Le greenways come fattore di resilienza dei Paesaggi agrari tradizionali in ambiente periurbano. In Ippolito, A. M. \& Clemente, M., eds., Necessità di agire per la costruzione del paesaggio futuro (pp. 114-119). Milano: Franco Angeli.

[13] Paresishvili, O., Kvaratskhelia, L. \& Mirzaeva, V. (2017). Rural tourism as a promising trend of small business in Georgia: Topicality, capabilities, peculiarities. Annals of Agrarian Science, 15(3), 344-348. DOI: 10.1016/j.aasci.2017.07.008.

[14] Santos, M. G. M. P. (2003). Religious tourism: Contributions towards a clarification of concepts. In Fernandes, C., McGettigan, F. \& Edwards, J., eds., Religious tourism and pilgrimage (pp. 27-43). Fatima: Tourism Board of Leiria/Fatima.

[15] Smith, V. L. (1992). The quest in guest. Annals of Tourism Research 19(1), 1-17. DOI: 10.1016/0160-7383(92)90103-V.

[16] Steiner, G., Losa, M. V. \& Riemen, R. (2006). Una certa idea di Europa. Milano: Garzanti.

[17] Timothy, D. J. \& Olsen, D. H. (2006). Tourism, religion and spiritual journeys. London; New York: Routledge. 
[18] Turri, E. (1998). Il paesaggio come Teatro. Venezia: Marsilio.

Other sources

[19] Canalis, X. (2010). El turismo religioso sigue moviendo montañas. Revista Hosteltur, novembre, 46-47.

[20] CIIC International Scientific Committee on Cultural Routes (CIIC) of ICOMOS (2008). ICOMOS Charter on Cultural Routes, Québec, Canada, October 2008.

[21] Ministero dei Beni e delle Attività culturali e del Turismo - MiBACT. 2016. Atlante dei Cammini d'Italia. Retrieved from: http://www.turismo.beniculturali.it/home-cammini-ditalia/atlante-deicamminil.

[22] UNESCO Operational Guidelines for the Implementation of the World Heritage Convention, Paris, November 2011. 